\title{
GIZI DAN 1000 HPK
}

\author{
Thontowi Djauhari NS \\ Bagian Anatomi Fakultas Kedokteran Universitas Muhammadiyah Malang \\ J1. Bendungan Sutami No. 188a Malang
}

\author{
Email : thontowi@yahoo.com
}

\begin{abstract}
ABSTRAK
Masalah gizi di Indonesia meliputi masalah kekurangan gizi dan kelebihan gizi. Beban gizi ganda atau Double Burden of Malnutrition (DBM) adalah suatu keadaan ko-eksistensi antara kekurangan gizi dan kelebihan gizi makronutrien maupun mikronutrien di sepanjang kehidupan. Stunting adalah kondisi gagal tumbuh pada anak akibat dari kekurangan gizi kronis sehingga anak terlalu pendek untuk usianya. Asupan energi dan zat gizi yang tidak memadai, serta penyakit infeksi merupakan faktor yang sangat berperan terhadap masalah stunting. Pemerintah Indonesia meluncurkan "Gerakan 1.000 Hari Pertama Kehidupan” yang dikenal sebagai 1.000 HPK. (Hari Pertama Kehidupan) Gerakan ini bertujuan mempercepat perbaikan gizi untuk memperbaiki kehidupan anak-anak Indonesia di masa mendatang. Tumbuh kembang anak perlu diperhatikan setelah dua tahun, kerena tumbuh kejar (catch up) masih akan berkembang lagi sampai usia pubertas. Tiga fase dalam tumbuh kembang, fase perlambatan tajam komponen bayi mempresentasikan pada pertumbuhan fetal, fase perlambatan perlahan komponen anak yang dimulai dari paruh kedua masa bayi dan berlanjut sampai maturitas, dan fase pubertas dimana pertumbuhan anak akan berlanjut. Pada tiap fase tersebut regulator hormon berbeda, sehingga intervensi gizi yang diberikan tentunya harus speseifik. Dapat disimpulkan perbaikan dalam tumbuh kembang anak setelah masa gagal tumbuh awal masih bisa diintervensi untuk mencegah gagal tumbuh, sehingga perlu penambahan program 1000 HPK plus untuk mencapai keberhasilan dari program yang telah dicanangkan.
\end{abstract}

Katra Kunci : Stunting, Tumbuh Kejar (Catch Up ), 1000 HPK

\section{ABSTRACT}

Nutritional problems in Indonesia include malnutrition and excess nutrients. Double nutritional burden or Double Burden of Malnutrition (DBM) is a coexistence state between malnutrition and macronutrient excess nutrients as well as micronutrients throughout life. Stunting is a condition of failure to grow in children resulting from chronic malnutrition so the child is too short for his age. Inadequate energy and nutrient intake, as well as infectious diseases are very important contributors to the stunting problem. The Government of Indonesia launched the "1.000 First Day of Life Movement" known as 1,000 HPK. (First Day of Life) This movement aims to accelerate the improvement of nutrition to improve the lives of Indonesian children in the future. Child growth needs to be noticed after two years, as it grows catch-up (catch up) will still grow again until the age of puberty. Three phases in growth, a sharp deceleration phase of the infant component presented in the fetal growth, slowing phase of the child component beginning in the second half of the infant and progressing to maturity, and the pubertal phase where the child's growth will continue. At each phase the hormone regulator is different, so the nutritional intervention given must be specific. It can be concluded that improvements in child growth after the initial failure period can still be intervened to prevent failure to grow, so the need for additional 1000 HPK plus programs to achieve the success of the program that has been declared.

Keywords : Stunting, Growing Up (Catch Up), 1000 HPK 


\section{PENDAHULUAN}

Masalah gizi di Indonesia meliputi masalah kekurangan gizi dan kelebihan gizi. Masalah kekurangan gizi yang mendapat banyak perhatian akhir-akhir ini adalah masalah kurang gizi kronis dalam bentuk anak pendek atau "stunting", kurang gizi akut dalam bentuk anak kurus atau "wasting". Kemiskinan dan rendahnya pendidikan dipandang sebagai akar penyebab kekurangan gizi. Masalah kegemukan terkait dengan berbagai penyakit tidak menular (PTM), seperti penyakit jantung, hipertensi, diabetes, stroke dan kanker paru-paru dianggap masalah negara maju dan kaya, bukan masalah negara berkembang dan miskin. Kenyataan menunjukkan bahwa kedua masalah gizi tersebut saat ini juga terjadi di negara berkembang. Dengan demikian negara berkembang dan miskin saat ini mempunyai beban ganda akibat kedua masalah gizi tersebut.

Beban gizi ganda atau Double Burden of Malnutrition (DBM) adalah suatu keadaan koeksistensi antara kekurangan gizi dan kelebihan gizi makronutrien maupun mikronutrien di sepanjang kehidupan pada populasi, masyarakat, keluarga dan bahkan individu yang sama (WHO, 2010). Dikhawatirkan dimensi DBM di sepanjang kehidupan, atau keterkaitan antara gizi buruk pada ibu hamil dan janin dengan meningkatnya kerentanan terhadap kelebihan gizi dan pola makan yang terkait penyakit tidak menular di kemudian hari.

Pemerintah Indonesia meluncurkan "Gerakan 1.000 Hari Pertama Kehidupan" yang dikenal sebagai 1.000 HPK. Masa 1000 hari pertama kehidupan (HPK), yang bermula sejak saat konsepsi hingga anak berusia 2 tahun, merupakan masa paling kritis untuk memperbaiki perkembangan fisik dan kognitif anak.

Beberapa penelitian melaporkan bahwa tumbuh kembang anak tidak hanya pada 2 tahun pertama saja, jika pemerintah hanya terfokus pada 1000 HPK tanpa melihat perkembangan berikutnya, maka pasca program 1000 HPK akan bermunculan masalah gizi yang lain. Kesimpulannya, masalah gizi di Indonesia harus dilakukan dengan cara terus menerus dan berkesinambungan dan melibatkan kerja sama antar pemangku kebijakan dupaya mendapatkan hasil yang lebih baik.

\section{Stunting}

Pertumbuhan pada dua tahun pertama kehidupan dicirikan dengan pertambahan gradual, baik pada percepatan pertumbuhan linear maupun laju pertambahan berat badan. Pertumbuhan bayi cenderung ditandai dengan pertumbuhan cepat (growth spurt) yang dimulai pada usia 3 bulan hingga usia 2 tahun, kemudian pertumbuhan pada anak pada usia 2 tahun sampai usia anak 5 tahun menjadi lebih lambat dibandingkan dengan ketika masih bayi, walaupun pertumbuhan terus berlanjut dan akan memengaruhi kemampuan motoris, sosial, emosional, dan perkembangan kognitif.(Astari, 2006). Stunting juga dapat merugikan kesehatan jangka panjang, dan pada saat dewasa dapat mempengaruhi produktivitas kerja, komplikasi persalinan, dan meningkatnya risiko kegemukan dan obesitas yang dapat memicu penyakit sindrom metabolik seperti penyakit jantung koroner, stroke, hipertensi, dan diabetes mellitus tipe 2 (Stuijvenberg, 2015. WHO, 2014).

Pertumbuhan linear yang tidak sesuai umur merefleksikan masalah gizi kurang. Gangguan pertumbuhan linier (stunting) akan berdampak terhadap pertumbuhan, perkembangan, kesehatan, dan produktivitas. Masalah gizi kurang jika tidak ditangani akan menimbulkan masalah yang lebih besar, bangsa Indonesia dapat mengalami lost generation.(Riskesdas, 2013)

Stunting dapat terjadi mulai janin masih dalam kandungan dan baru nampak saat anak berusia dua tahun (Millennium Challenga Account Indonesia, 2014). Stunting yang telah tejadi bila tidak diimbangi dengan catch-up growth (tumbuh kejar) mengakibatkan menurunnya pertumbuhan, masalah stunting merupakan masalah kesehatan masyarakat yang berhubungan dengan meningkatnya risiko kesakitan, kematian dan hambatan pada pertumbuhan baik motorik maupun mental. Stunting dibentuk oleh growth faltering dan catcth up growth yang tidak memadai yang mencerminkan ketidakmampuan untuk mencapai pertumbuhan optimal, hal tersebut mengungkapkan bahwa kelompok balita yang lahir dengan berat badan normal dapat mengalami stunting bila pemenuhan kebutuhan selanjutnya tidak terpenuhi dengan baik.(Kusharisupeni, 2008)

Stunting adalah kondisi gagal tumbuh pada anak akibat dari kekurangan gizi kronis sehingga anak terlalu pendek untuk usianya. Kekurangan gizi 
terjadi sejak bayi dalam kandungan dan pada masa awal setelah bayi lahir akan tetapi, kondisi stunting baru nampak setelah bayi berusia 2 tahun. Balita pendek (stunted) dan sangat pendek (severely stunted) adalah balita dengan panjang badan (PB/U) atau tinggi badan (TB/U) menurut umurnya dibandingkan dengan standar baku WHO-MGRS (Multicentre Growth Reference Study) 2006. Sedangkan definisi stunting menurut Kementerian Kesehatan (Kemenkes) adalah anak balita dengan nilai zscorenya kurang dari -2SD/standar deviasi (stunted) dan kurang dari - 3SD (severely stunted).

Hasil Riset Kesehatan Dasar (Riskesdas ) Indonesia tahun 2013, sekitar 37\% (hampir 9 Juta) anak balita mengalami stunting dan naik menjadi 44 $\%$ (UNICEF, 2013), Indonesia adalah negara dengan prevalensi stunting kelima terbesar. Balita/ Baduta (Bayi dibawah usia Dua Tahun) yang mengalami stunting akan memiliki tingkat kecerdasan tidak maksimal, menjadikan anak menjadi lebih rentan terhadap penyakit dan di masa depan dapat beresiko pada menurunnya tingkat produktivitas. Pada akhirnya secara luas stunting akan dapat menghambat pertumbuhan ekonomi, meningkatkan kemiskinan dan memperlebar ketimpangan.

Stunting merupakan kondisi kronis yang menggambarkan terhambatnya pertumbuhan karena malnutrisi jangka panjang. Stunting menurut WHO Child Growth Standart didasarkan pada indeks panjang badan dibanding umur $(\mathrm{PB} / \mathrm{U})$ atau tinggi badan dibanding umur (TB/U) dengan batas (₹score) kurang dari -2 SD. Secara global, sekitar 1 dari 4 balita mengalami stunting (UNICEF, 2013).

Stunting pada anak balita merupakan konsekuensi dari beberapa faktor yang sering dikaitkan dengan kemiskinan termasuk gizi, kesehatan, sanitasi dan lingkungan. Ada lima faktor utama penyebab stunting yaitu kemiskinan, sosial dan budaya, peningkatan paparan terhadap penyakit infeksi, kerawanan pangan dan akses masyarakat terhadap pelayanan kesehatan (Riskesdas, 2013). Faktor lain yang berkontribusi terhadap stunting tersebut adalah tinggi badan ayah; riwayat berat badan lahir rendah; riwayat gizi kurang; kurangnya pemanfaatan posyandu dan perilaku higiene; ketidaksesuaian dalam pemberian makanan pendamping dan pelengkap serta secara kuantitas dan kualitas gizi makanan yang diberikan kurang; praktik menyusui dan praktik pemberian makan (Ulfani, 2011). Faktor yang berhubungan dengan status gizi kronis pada anak balita tidak sama antara wilayah perkotaan dan pedesaan, sehingga upaya penanggulangannya harus disesuaikan dengan faktor yang mempengaruhi.

Stunting adalah masalah gizi utama yang akan berdampak pada kehidupan sosial dan ekonomi dalam masyarakat. Selain itu, stunting dapat berpengaruh pada anak balita pada jangka panjang yaitu mengganggu kesehatan, pendidikan serta produktifitasnya di kemudian hari. Anak balita stunting cenderung akan sulit mencapai potensi pertumbuhan dan perkembangan yang optimal baik secara fisik maupun psikomotorik (Bappenas RI, 2012).

\section{Epidemiologi Stunting}

Menurut UNICEF, tahun 2011 ada 165 juta $(26 \%)$ balita dengan stunting di seluruh dunia. Indonesia termasuk dalam 5 negara dengan angka balita stunting tertinggi yaitu 7,5 juta balita (UNICEF, 2013). Prevalensi stunting di Indonesia lebih tinggi daripada negara-negara lain di Asia Tenggara, seperti Myanmar (35\%), Vietnam (23\%), dan Thailand (16\%) Millennium Challenga Account Indonesia, 2014).

Riset Kesehatan Dasar (Riskesdas) pada tahun 2013 diketahui bahwa prevalensi kejadian stunting secara nasional adalah 37,2 \%, dimana terdiri dari 18,0 \% sangat pendek dan 19,2 \% pendek, yang berarti telah terjadi peningkatan sebanyak 1,6 \% pada tahun 2010 (35,6 \%) dan tahun 2007 (36,8 \%). Prevalensi stunting (TB/U) lebih tinggi dibandingkan dengan prevalensi kejadian underweight atau gizi buruk (BB/U) (19,6 \%) dan prevalensi kejadian wasting atau kurus (BB/TB) (5,3 \%). Pada anak balita di Indonesia (Badan Pengembangan \& Penelitian Kesehatan, 2013).

Penilaian Antropometri digunakan untuk melihat ketidakseimbangan asupan protein dan energi.(16) Beberapa indeks antropometri yang sering digunakan adalah berat badan menurut umur $(\mathrm{BB} / \mathrm{U})$, tinggi badan menurut umur $(\mathrm{TB} / \mathrm{U})$, berat badan menurut tinggi badan (BB/TB) yang dinyatakan dengan standar deviasi unit $\mathrm{Z}$ ( $\mathrm{Z}$ score).(13) Stunting dapat diketahui bila seorang balita sudah ditimbang berat badannya dan diukur panjang atau tinggi badannya, lalu dibandingkan dengan standar, dan hasilnya berada dibawah normal. Jadi secara fisik balita akan lebih pendek dibandingkan balita seumurnya. Penghitungan ini 
menggunakan standar Z score dari WHO. Normal, pendek dan Sangat Pendek adalah status gizi yang didasarkan pada indeks Panjang Badan menurut Umur (PB/U) atau Tinggi Badan menurut Umur (TB/U) yang merupakan padanan istilah stunted (pendek) dan severely stunted (sangat pendek).

Klasifikasi status gizi stunting berdasarkan indikator tinggi badan per umur (TB/U). (6)

I Sangat pendek : Zscore $<-3,0$

II Pendek : Zscore $<-2,0$ s.d. Zscore e" $-3,0$

III Normal : Zscore e" $-2,013$

Klasifikasi status gizi stunting berdasarkan indikator TB/U dan BB/TB.( 6)

I Pendek-kurus : -Zscore TB/U $<-2,0$ dan Zscore $\mathrm{BB} / \mathrm{TB}<-2,0$

II Pendek-normal : Z-score TB/U $<-2,0$ dan Zscore BB/TB antara $-2,0 \mathrm{~s} / \mathrm{d} 2,0$

III Pendek-gemuk : Z-score e" -2,0 s/d Zscore d" 2,0

\section{Nutrisi dan Pembentukan Tulang}

Asupan energi dan zat gizi yang tidak memadai, serta penyakit infeksi merupakan faktor yang sangat berperan terhadap masalah stunting. Kuantitas dan kualitas dari asupan protein memiliki efek terhadap level plasma insulin growth factor I (IGF-I) dan juga terhadap protein matriks tulang serta faktor pertumbuhan yang berperan penting dalam formasi tulang (Mikhail, 2013). Selain itu, di dalam Lancet Series dijelaskan mengenai beberapa zat gizi mikro yang sangat penting untuk mencegah terjadinya stunting yaitu vitamin A, zinc, zat besi dan iodin (Souganidis, 2012). Yodium diperlukan untuk membentuk hormon tiroksin yang diperlukan oleh tubuh untuk mengatur pertumbuhan dan perkembangan mulai dari janin sampai dewasa. (Waterlow JC. 1998). Dari beberapa studi dikemukakan bahwa kekurangan yodium dapat berakibat antara lain pada gangguan pertumbuhan fisik dan keterbelakangan mental (Zabraini, 2009). Namun, beberapa zat gizi mikro lainnya seperti kalsium dan fosfor juga sangat penting perannya dalam pertumbuhan linier anak (Stuijvenberg, 2015, Mikhail, 2013).

Selama pertumbuhan, tuntutan terhadap mineralisasi tulang sangat tinggi, rendahnya asupan kalsium dapat mengakibatkan rendahnya mineralisasi matriks deposit tulang baru dan disfungsi osteoblast
(Khairy, 2010). Defisiensi kalsium akan mempengaruhi pertumbuhan linier jika kandungan kalsium dalam tulang kurang dari 50\% kandungan normal (Prentice, 1993). Kalsium membentuk ikatan kompleks dengan fosfat yang dapat memberikan kekuatan pada tulang, sehingga defisiensi fosfor dapat mengganggu pertumbuhan. Defisiensi fosfor yang berlangsung lama akan menyebabkan osteomalasia dan dapat menyebabkan pelepasan kalsium dari tulang (Mikhail, 2013).

Selain kalsium, fosfor, energi, dan vitamin, satu liter susu menyediakan 32-35 gram protein, sebagian besar casein dan whey yang mengandung banyak unsur pertumbuhan (Asrar, 2009). Casein dapat meningkatkan penyerapan kalsium dan retensi mineral. Menghindari susu selama masa pertumbuhan anak dikaitkan dengan perawakan pendek dan massa mineral tulang yang lebih rendah (Black, 2002).

Asupan protein menyediakan asam amino yang diperlukan tubuh untuk membangun matriks tulang dan mempengaruhi pertumbuhan tulang karena protein berfungsi untuk memodifikasi sekresi dan aksi osteotropic hormone IGF-I, sehingga, asupan protein dapat memodulasi potensi genetik dari pencapaian peak bone mass. Asupan protein rendah terbukti merusak akuisisi mineral massa tulang dengan merusak produksi dan efek IGF-I. IGF-I mempengaruhi pertumbuhan tulang dengan merangsang proliferasi dan diferensiasi kondrosit di lempeng epifisis pertumbuhan dan langsung mempengaruhi osteoblas. Selain itu, IGF-I meningkatkan konversi ginjal dari 25 hidroksivitamin D3 menjadi aktif hormon 1,25 dihidroksivitamin D3 dan dengan demikian memberikan kontribusi untuk peningkatan penyerapan kalsium dan fosfor di usus (Prentice, 1993, Bourrin, 2000, Li J, 2012).

Selama pertumbuhan, tuntutan terhadap mineralisasi tulang sangat tinggi, asupan kalsium yang sangat rendah dapat menyebabkan hipokalsemia, meskipun sekresi dari kelenjar paratiroid maksimal, yang dapat mengakibatkan rendahnya mineralisasi matriks deposit tulang baru dan disfungsi osteoblas (Khairy, 2010). Defisiensi kalsium akan mempengaruhi pertumbuhan linier jika kandungan kalsium dalam tulang kurang dari 50\% kandungan normal (Prentice, 1993). Pada bayi, kekurangan kalsium di dalam tulang dapat menyebabkan rakitis, sedangkan pada anak-anak, 
kekurangan deposit dapat menyebabkan terhambatnya pertumbuhan (Millennium Challenga Account Indonesia, 2014).

Deposit kalsium dan fosfor di dalam matriks organik berbentuk kristal hidroksiapatit selama proses mineralisasi dan memberikan kekuatan pada tulang. Defisiensi kedua mineral ini atau rasio yang tidak tepat dapat mempengaruhi pertumbuhan tulang (24). Perbandingan yang seimbang antara kalsium dan fosfor dapat membantu penyerapan kalsium. Tubuh akan menjaga rasio kalsium : fosfor $2: 1$ atau $1: 1$, suatu rasio yang vital untuk pertumbuhan tulang yang ideal karena fosfat anorganik memiliki banyak peran dalam proses biologis seperti metabolisme sel, penanda sel, sebagai koenzim, metabolisme nukleotida, metabolisme energi, fungsi membran, dan mineralisasi tulang (Asrar, 2009).

Homeostasis Fosfor terutama ditentukan oleh asupan makanan, penyerapan usus, dan reabsorpsi tubulus ginjal fosfor. Namun bila kadar fosfor relatif tinggi terhadap kalsium maka akan diperoleh rasio kalsium : fosfor yang tidak seimbang dalam serum sehingga akan merangsang pembentukan PTH yang mendorong pengeluaran fosfor dari tubuh. Asupan tinggi fosfor dapat mengakibatkan peningkatan sekresi serum PTH dan mempengaruhi metabolisme tulang. Dalam jangka panjang, asupan tinggi fosfor bisa menyebabkan hiperparatiroidisme sekunder, peningkatan resorpsi tulang, dan rendahnya kualitas tulang, terutama jika asupan kalsium tidak memadai (Bourrin, 2000).

Selain berperan dalam mineralisasi tulang, fosfor sebagai fosfat organik memegang peranan penting dalam reaksi yang berkaitan dengan penyimpanan atau pelepasan energi dalam bentuk Adenin Trifosfat (ATP). Oksidasi bahan bakar metabolism dikendalikan oleh ketersediaan ADP yang selanjutnya dikendalikan oleh tingkat dimana ATP digunakan untuk aktifitas fisik dan metabolisme. Fosfor ikut dalam pengaktifan beberapa reaksi dalam semua metabolism (Gibson, 2007).

\section{Dampak panjang beban ganda malnutrisi}

Kekurangan gizi pada anak-anak bisa mulai terjadi pada tahap sangat awal dalam hidup. Saat seorang anak menerima asupan gizi yang kurang baik saat masih dalam kandungan, tubuhnya akan "terprogram" agar bisa bertahan hidup dalam kondisi gizi yang kurang. Akibat "pemrograman" ini, apabila kelak ia hidup dalam lingkungan dengan asupan gizi yang mudah diperoleh, tubuh mereka akan sangat rentan terhadap obesitas sehingga mudah terkena penyakit tidak menular seperti diabetes dan jantung. Stunting adalah tanda kurang gizi kronis, dan dampak paling merugikan adalah terhadap perkembangan otak: Stunting mengurangi IQ sebesar 5-11 poin, Nilai sekolah anak-anak jadi lebih rendah, Anak-anak yang lahir dengan berat badan kurang punya peluang 2,6 kali lebih kecil untuk melanjutkan ke pendidikan tinggi, Pemasukan anak-anak dengan stunting 10 persen lebih rendah. Saat anak terkena stunting, produktivitas mereka akan berkurang saat usia muda - capaian pendidikan lebih rendah menghasilkan pekerjaan dengan pemasukan lebih kecil. Bila diiukti dengan kenaikan berat badan tinggi saat tua, mereka akan berisiko terkena obesitas dan penyakit lain yang terkait pola makan. Ini adalah beban ganda malnutrisi.(World Bank, 2015).

Dampak beban ganda malnutrisi tidak hanya dirasakan individu. Ekonomi juga terkena dampaknya; kerugian akibat stunting dan malnutrisi diperkirakan setara dengan 2-3\% PDB Indonesia. "Semakin banyak kasus penyakit tidak menular di Indonesia telah mengakibatkan naiknya pengeluaran bagi pemerintah, khususnya untuk jaminan kesehatan nasional, Biaya tertinggi jaminan kesehatan nasional adalah untuk perawatan stroke, diabetes dan gagal ginjal. Penyakit tidak menular kini menjadi penyebab 60\% kematian. Beban ganda malnutrisi jelas menjadi masalah bagi Indonesia dan memerlukan perhatian lebih. Beban ganda malnutrisi juga akan menghambat potensi dari transisi demografis Indonesia, dimana rasio penduduk usia tidak bekerja terhadap penduduk usia kerja akan menurun. "Kondisi ini yang seharusnya menjadi bonus demografi bisa menjadi beban demografi,".(World Bank, 2015).

Efek gizi kurang di dalam kandungan dapat memanjang ke 3 generasi, seperti diindikasikan oleh hubungan antara ukuran Tinggi Badan nenek dan berat badan lahir bayi yg dilahirkan oleh wanita dlm studi kohort (Victora 2008). Bukti dari India: anak yg gizi kurang, cenderung menjadi dewasa pendek, selanjutnya cenderung melahirkan bayi kecil , yg berisiko mempunyai risiko berprestasi 
pendidikan yg rendah, dan pada akhirnya mempunyai status ekonomi yg rendah. (Chandrakant 2008.)

\section{Program 1000 hari}

Pada bulan September 2012, Pemerintah Indonesia meluncurkan "Gerakan 1.000 Hari Pertama Kehidupan” yang dikenal sebagai 1.000 HPK. Gerakan ini bertujuan mempercepat perbaikan gizi untuk memperbaiki kehidupan anak-anak Indonesia di masa mendatang. Gerakan ini melibatkan berbagai sektor dan pemangku kebijakan untuk bekerjasama menurunkan prevalensi stunting serta bentuk-bentuk kurang gizi lainnya di Indonesia.

Masa 1000 hari pertama kehidupan (HPK), yang bermula sejak saat konsepsi hingga anak berusia 2 tahun, merupakan masa paling kritis untuk memperbaiki perkembangan fisik dan kognitif anak. Status gizi ibu hamil dan ibu menyusui, status kesehatan dan asupan gizi yang baik merupakan faktor penting untuk pertumbuhan dan perkembangan fisik dan kognitif anak, menurunkan risiko kesakitan pada bayi dan ibu. Ibu hamil dengan status gizi kurang akan menyebabkan gangguan pertumbuhan janin, penyebab utama terjadinya bayi pendek (stunting) dan meningkatkan risiko obesitas dan penyakit degeneratif pada masa dewasa.(World Bank, 2012)

Status gizi pada 1000 HPK akan berpengaruh terhadap kualitas kesehatan, intelektual, dan produktivitas pada masa yang akan datang [USAI, 2014]. Ibu dan bayi memerlukan gizi yang cukup dan berkualitas untuk menjamin status gizi dan status kesehatan; kemampuan motorik, sosial, dan kognitif; kemampuan belajar dan produktivitasnya pada masa yang akan datang. Anak yang mengalami kekurangan gizi pada masa 1000 HPK akan mengalami masalah neurologis, penurunan kemampuan belajar, peningkatan risiko drop out dari sekolah, penurunan produktivitas dan kemampuan bekerja, penurunan pendapatan, penurunan kemampuan menyediakan makananan yang bergizi dan penurunan kemampuan mengasuh anak. Selanjutnya akan menghasilkan penularan kurang gizi dan kemiskinan pada generasi selanjutnya .(World Bank, 2015, USAID 2014). Mempertimbangkan pentingnya gizi bagi $1000 \mathrm{HPK}$, maka intervensi gizi pada 1000 HPK merupakan prioritas utama untuk meningkatkan kualitas kehidupan generasi yang akan datang [Bappenas RI, 2012].
Intervensi pada 1000 HPK difokuskan pada 2 jenis intervensi, yaitu intervensi gizi spesifik dan intervensi gizi sensitif. Intervensi gizi spesifik merupakan rangkaian berbagai kegiatan yang cukup cost effective khususnya untuk mengatasi masalah gizi pendek, sedangkan intervensi gizi sensitif merupakan berbagai kegiatan program pembangunan yang memberi pengaruh pada status gizi masyarakat terutama kelompok 1000 HPK, seperti penanggulangan kemiskinan, pendidikan, gender, air bersih, sanitasi, serta kesehatan lingkungan (Bappenas RI 2012, Ulfani, 2011).

Mengingat masalah gizi 1000 HPK merupakan masalah yang multifaktorial, maka program pengentasan masalah 1000 HPK harus bersifat sensitif dan spesifik dan harus diselesaikan secara integratif melalui koordinasi yang baik antar berbagai sektor terkait, serta didasarkan pada akar masalah yang ada (Ulfani, 2011). Untuk itu, agar dapat merencanakan intervensi gizi fokus pada 1000 HPK, diperlukan identifikasi masalah untuk menggambarkan masalah gizi yang dihadapi oleh kelompok sasaran 1000 HPK di wilayah yang kemungkinan dapat mempengaruhi.

Scalling Up Nutrition Movement (The SUN Movement) program United Nation General Assembly pada bulan Oktober 2010. Gerakan ini sebagai respon untuk mengatasi kompleksnya masalah gizi dan kesehatan ibu dan anak yang peluncuran gerakan ini dilakukan dalam pertemuan Bank Dunia (World Bank) dan International Monetary Fund (IMF). Pada saat itu dikenalkan suatu kerangka kerja sebagai solusi untuk mengatasi masalah malnutrisi dalam upaya yang bersifat kolektif dan terpadu dimana semua stakeholder, termasuk pemerintah, akademisi, masyarakat, organisasi dibawah United Nation (WHO, UNICEF, FAO dan lainnya), Develompment Bank, dan kelompok bisnis, mengambil peran spesifik masing-masing untuk menjamin bahwa intervensi dilaksanakan secara merata dan dalam skala masingmasing (Nabarro, 2013).

Bentuk intervensi dan program untuk mengatasi masalah gizi ibu dan anak yang bersifat multi sektor dan multi pendekatan dapat dikategorikan menjadi dua, yaitu intervensi yang bersifat spesifik (nutrition-spesific intervention and programmes) dan intervensi yang bersifat sensitif (nutrition-sensitive intevention and programmes). Nutrition-specific intervention/programmes adalah 
suatu inetervensi atau program yang ditujukan untuk memperbaiki determinan jangka pendek (immediate determinants) dari kondisi gizi janin dan anak serta perkembangannya (Ruel et al., 2013; Andersen, 2013).

Mengacu pada SUN Framework, sebagian besar dari 13 intervensi di bidang gizi yang terbukti paling cost effective sudah dilaksanakan di Indonesia, namun hasilnya tidak efektif. Hal ini terutama karena masalah gizi sementara ini dianggap sebagai tanggung jawab sektor kesehatan semata. Sesungguhnya hanya 30\% masalah gizi yang bisa diselesaikan oleh sektor kesehatan, sedangkan 70\% lainnya harus dikerjakan oleh sektor lainnya. Karena sifatnya yang sangat multi faktorial dan multi sektoral, maka diperlukan satu kerangka kerja yang bersifat "Three Ones" atau Tiga-Satu yang telah disepakati, yaitu: 1) Satu kerangka kerja sebagai dasar untuk koordinasi kerja semua mitra; 2) Satu otoritas koordinasi tingkat nasional; 3) satu sistem monitoring dan evaluasi tingkat nasional (Achadi, 2013).

\section{Program 1000 HPK Plus}

Berdasarkan program 1000HPK, tumbuh kembang anak perlu diperhatikan setelah 2 tahun, kerena tumbuh kejar (catch up) masih akan berkembang lagi sampai usia pubertas. Temuan Shrimpton tahun 2001 dan Victoria tahun 2010 menyimpulkan, usia pertumbuhan bayi di afrika menunjukkan $2 / 3$ dari sampel mengalami kejar tumbuh antara 24-48 bulan. Menurut Prentice 2013, Analisis potong lintang shrimpton et al dan victoria et al telah di over interpretasi.

Masalah pertumbuhan sistim organ utama tubuh, untuk jaringan muskuloskeletal, pertumbuhan dibagi menjadi dua periode sensitif yaitu kurang dari lima tahun dan pubertas yang diantarai oleh masa tenang pertumbuhan (Prentice 2013). Kalberg pada tahun 1989 mengatakan, tiga fase dalam tumbuh kembang, fase perlambatan tajam komponen bayi mempresentasikan pada pertumbuhan fetal, fase perlambatan perlahan komponen anak yang dimulai dari paruh kedua masa bayi dan berlanjut sampai maturitas, dan fase pubertas dimana pertumbuhan anak akan berlanjut. Pada tiap fase tersebut regulator hormon berbeda, sehingga intervensi gizi yang diberikan tentunya harus speseifik. Pada fase bayi, IGF ( Insulin Growth Faktor ) lebih berperan, sehingga protein dan yang mirip insulin diperlukan. Pda fase anak diperlukan GH (Growth Hormon ) dan diikuti fase Puber yang memerlukan hormon seksual (estrogen dan Testosteron).

Kesimpulannya Perbaikan dalam tumbuh kembang anak setelah masa gagal tumbuh awal masih bisa diintervensi untuk mencegah gagal tumbuh jika melihat pendapat diatas, sehingga perlu penambahan program 1000 HPK plus untuk mencapai keberhasilan dari program yang telah dicanagkan pemerintah.

\section{DAFTAR PUSTAKA}

Asrar M, Hadi H, Boediman D. Hubungan pola asuh, 16. pola makan, asupan zat gizi dengan status gizi anak balita masyarakat Suku Nuaulu di Kecamatan Amahai Kabupaten Maluku Tengah Provinsi Maluku. Jurnal Gizi Klinik Indonesia 2009;6(2):84-94.

Astari LD 2006. Faktor-Faktor yang Berpengaruh terhadap Kejadian Stunting Anak Usia 6-12 Bulan di Kabupaten Bogor. Tesis. Bogor: Sekolah Pascasarjana Institut Pertanian Bogor,

Badan Penelitian dan Pengembangan Kesehatan Kementerian Kesehatan RI. Riset kesehatan dasar (Riskesdas) 2013 : http:// www.depkes.go.id/resources/download/ general/Hasil\%20Riskesdas\%20 2013.pdf

Badan Pengembangan \& Penelitian Kesehatan.(2013). Riset Kesehatan Dasar tahun 2013. Departemen Kesehatan Republik Indonesia.

BAPPENAS RI. Pedoman Perencanaan Program Gerakan Sadar Gizi dalam Rangka Seribu Hari Pertama Kehidupan (1000 HPK); 2012. 1-8

Black RE, Williams SM, Jones IE, Goulding A. 17. Children who avoid drinking cow milk have low dietary calcium intakes and poor bone health. Am J Clin Nutr 2002;76(3):675-80.

Bourrin S, Ammann P, Bonjour JP, Rizzoli R. Dietary 18. protein restriction lowers plasma insulin-like growth factor I (IGF-I), impairs cortical bone formation, and induces osteoblastic resistance to IGF-I in adult female rats. Endocrinology 2000;141(9):314955. 
Chandrakant L 2008. The Lancet Series and Indian Perspective. Indian Pediatrics, Volume 45, April 17, 2008.

Dewey KG dan Begum K. Long-term Consequences Of Stunting In Early Life. Blackwell Publishing Ltd Maternal and Child Nutrition. NCBI. 2011: Vol (7): 5-]

Direktorat Jenderal Bina Gizi dan Kesehatan Ibu dan Anak. Kemenkes RI no195/MENKES/ SK/XII/2010: Standar antropometri penilaian status gizi anak. Jakarta; 2011.

Gibson RS, Manger MS, Krittaphol W, Pongcharoen 22. T, Gowachirapant S, Winichagoon P, et al. Does zinc deficiency play a role in stunting among primary school children in Thailand. Br J Nutr 2007;97(1):167-75.

Kementerian Kesehatan RI. Laporan Hasil Riset Kesehatan Dasar (Riskesdas) Tahun 2013 [internet]: Status Gizi Anak Balita. Jakarta: Badan Penelitian dan Pengembangan Kesehatan; 2013

Kementerian Perencanaan Pembangunan Nasional (Bappenas) dan United Nations Children's Fund (2017). Laporan Baseline SDG tentang Anak-Anak di Indonesia Jakarta: BAPPENAS dan UNICEF

Khairy SAM, Mattar MK, Refaat LAM, El-Sherbeny SA. 9. Plasma micronutrient levels of stunted Egyptian school age children. Kasr El Aini Med J 2010;16(1).

Kusharisupeni. Gizi dalam daur kehidupan (prinsipprinsip dasar). Dalam Depertemen Gizi dan Kesehatan Masyarakat, FKM UI, editor. Gizi dan kesehatan masyarakat. Edisi Revisi. Jakarta: PT Raja Grafindo Persada; 2008: h.149-168

Li j, Yuan J, Guo Y, Sun Q, Hu X. The influence of dietary 24. calcium and phosphorus imbalance on intestinal $\mathrm{NaPi}-\mathrm{IIb}$ and Calbindin mRNA Expression and tibia parameters of broilers. Asian-Aust J Anim 2012;25(4):552-8.

Mikhail WZA, Sabhy HM, El-sayed HH, Khairy SA, Salem 7. HYHA, Samy MA. Effect of nutritional status on growth pattern of stunted preschool children in Egypt. Acad J Nutr 2013;2(1):1-9.

Millennium Challenga Account Indonesia. 2014. Stunting dan Masa Depan Indonesia
Millennium Challenge Account - Indonesia. Backgrounder : stunting dan masa depan indonesia [Internet]; 2015.

Peacock M. Calcium metabolism in health and disease. 23. Clin J Am Soc Nephrol 2010;5(Suppl 1):S23-30.

Prentice A, Bates CJ. An appraisal of the adequacy 10. of dietary mineral intakes in developing countries for bone growth and development in children. Nutr Res Rev 1993;6(1):51-69.

Sa'dillah F. Ulasan Singkat FAO 2014: Peluang dan tantangan sektor perikanan [Internet]; 2014.

Soekirman. 2005. Perlu Paradigma Baru untuk Menanggulangi Masalah Gizi Makro di Indonesia. Jakarta: untuk Menanggulangi Masalah Gizi Makro di Indonesia. Jakarta: http:/ /www.gizi.net/makalah/download/ prof-soekirman.pdf. Diakses tanggal 9 April 2009

Souganidis E. The relevance of micronutrients to the 8 . prevention of stunting. Sight and life 2012;26(2).

Stuijvenberg ME, Nel J, Schoeman SE, Lombard CJ, du 5. Plessis LM, Dhansay MA. Low intake of calcium and vitamin $\mathrm{D}$, but not zinc, iron or vitamin $A$, is associated with stunting in 2-5 years old children. Nutrition 2015;31:841-6

.The Lancet 2013. Maternal and Child Nutrition: Executive Summary of the Lancet Maternal and Child Nutrition Series. The Lancet; 2013. 1-12.

The World Bank Indonesia. Indonesia menghadapi beban ganda malnutrisi. Jakarta: The World Bank Indonesia, 2012.

Ulfani DH, Martianto D, Baliwati YF. FaktorFaktor Sosial Ekonomi dan Kesehatan Masyarakat Kaitannya dengan Masalah Gizi Underweight, Stunted, dan Wasted di Indonesia: Pendekatan Ekologi Gizi. Jurnal Gizi dan Pangan. 2011; 6(1): 63-4.

UNICEF. (2013). Improving child nutrition, the achievable imperative for global progress. New York: United Nations Children's Fund.

USAID. Multi-sectoral Nutrition Strategy 20142025 Technical Guidance Brief: Implementation Guidance for Ending 
Preventable Maternal and Child Death. 2014. 1-6.

Victora, et al, 2008. The Lancet's Series on Maternal and Child Undernutrition 2. 2008

Waterlow JC. Observations on the natural history of stunting. In: Waterlow JC, ed. Linear growth retardation in less developed countries. New York: Vevey/Raven Press, :1-16. Nestle Nutrition Workshop Series, vol 14.) 1988.

World Bank, Beban Ganda Malnutrisi Bagi Indonesia. Jakarta 2015.)

World Health Organization , 2010. Nutrition landscape information system (NLIS) country prfile indicators: intrepretation guide. Geneva: World Health Organization; 2010.

World Health Organization. WHA global nutrition targets 6. 2025: Stunting policy brief. Geneva: WHO; 2014

.Zahraini. Hubungan Status Gizi dan Status KADARSI. FakultasKesehatan Masyarakat. UI. 2009. 